UDC: 616-002.773:616.61-002-008:576.31:611.018.74

DOI: $10.15587 / 2519-4798.2017 .90861$

\title{
ANALYSIS OF MORPHOLOGICAL AND FUNCTIONAL CHANGES OF KIDNEY ENDOTHELIUM IN SYSTEMIC RHEUMATIC DISEASES
}

\section{(C) Ye. Iegudina}

\begin{abstract}
Метою роботи стала оцінка характеру морфологічних змін ендотелію судин нирок при системному червоному вовчаку, ревматоїдному артриті, геморагічному васкуліті та мікроскопічному поліангї̈ті, зв'язок з клініко-лабораторними чинниками перебігу захворювань і вплив системної ендотеліальної дисфункиї судин. Остання в циих групах хворих бере участь в патогенетичних побудовах нефропатії, щільно пов'язана з системними проявами ангіопатії
\end{abstract}

Ключові слова: нирки, ендотеліум, кровоносні судини, функція, системні ревматичні захворювання

\section{Introduction}

Vessels and vascular endothelium are involved in the pathogenesis of inflammatory rheumatic diseases. Systemic lupus erythematosus (SLE), rheumatoid arthritis (RA), Henoch-Schönlein purpura (HSP) and microscopic polyangiitis (MPA) combined into a group of systemic autoimmune rheumatic diseases (SRD) [1, 2], the prevalence of which is growing everywhere [3]. The commonness of these diseases is the presence of various autoantibodies in blood [4] and changes in the kidneys blood vessels [5]. Angiopathy is one of the main manifestations of SLE [6, 7] and RA [8-10], and as for patients with HSP and MPA, the vascular inflammatory process is already included in the definition of the names of diseases [11]. In patients with systemic autoimmune diseases, the prevention of kidney failure risk is now regarded as part of the global management along with controlling of disease activity and inflammation. Kidney vessels endothelial dysfunction and accelerated nephropathy are presented in the early years of the disease before nephropathy becomes apparent [12]. The widening of the mortality gap between SRD patients and the general population [13], calls for early identification of patients at higher risk in order to improve outcomes and introduce preventive and therapeutic strategies in early stages, when they are likely to be more effective.

\section{Case presentation}

The pathogenesis of renal damage vessels in lupus and rheumatoid glomerulonephritis (LGN, RGN) remains not adequately explored [14, 15], although the severity of the vasculopathy determines the prognosis both SLE [16] and RA [17]. The above fully applies to patients suffering from HSP and MPA [18].

It should be noted that SRD are characterized by disorders of vascular endothelial function [19] with the overproduction of vascular endothelial growth factor (VEGF) [20], endothelin-1 (ET1) [21] and E-selectin (ESel) [22]. These processes play an important role in the damage of glomerular capillaries and arterioles of the kidneys at SRD [23], which has been proved by experimental studies in animals [24]. Kidney endothelium responds to systemic vascular endothelial dysfunction (VED) firstly in the patients organism [25, 26].
At the same time, the nature of morphological changes in the endothelium of the kidneys capillaries and arterioles in SLE, RA, HSP and MPA studied insufficiently, to be elucidated the pathogenetic mechanisms of vascular deposition of immune components, the relationship with clinical and laboratory factors of the disease and the effect of systemic VED.

\section{Purpose}

The purpose of the work was to evaluate the nature of morphological changes in the endothelium of the kidneys capillaries and arterioles in SLE, RA, HSP and MPA, connection with clinical and laboratory factors of the disease course and the effect of systemic vascular endothelial dysfunction.

\section{Materials and methods}

Study was conducted on the basis of the Donetsk Regional Clinical Territorial Medical Association in Rheumatological department. Analyzed the results of kidney biopsy and laboratory studies of vascular endothelial function in 94 patients with HSP, among which 41 persons suffered from SLE, 17 - RA, $24-$ SHP and 12 - MPA. In these groups ratio of men and women, respectively, was as 1: 7, 1: 2, 2: 1 and 1: 3, the average age of the patients $-37.6 \pm 1.63$ years, $50.1 \pm$ \pm 2.33 years, $27,5 \pm 2.19$ years and $40,5 \pm 3,70$ years, the duration of the disease from its manifestation - 11,9 \pm $\pm 1,28$ years, $12,4 \pm 1,99$ years, $10,2 \pm 1,77$ years, $40 \pm$ $\pm 1,02$ years, distribution of patients I, II and III degree of activity of the pathological process - as a 1:2:3, 1:2:2, 2:1:1, 1:2:9. In SLE chronic course of the disease met 5 times more often than subacute, the RA ratio of I: II: III: IV disease stages was as 2:9:5:1, the rate of DAS arthritis activity was 4,9 $\pm 0,30$ r.u., and Lansburi index $155,8 \pm 13,35$ points; in SHP purely renal form of the disease, skin - joint - renal, skin - renal, joint-renal, skin - joint - abdominal - kidney, skin - abdominal renal, joint - abdominal - renal; abdominally - renal forms correlated in frequency 20:13:11:8:6:3:2:1. We studied the clinical course of the index angiopathy $(\Omega)$ the formula: $\Omega=(\Sigma: E) \times \Omega=(\Sigma: E) \cdot \sqrt{Y}$, where $\Sigma-$ sum of points of all clinical signs of SRD, E - the number of features, Y - the degree of disease activity. 
Patients underwent echocardiography («Acuson-Aspen-Siemens», Germany, and «HD-11-XEPhilips», the Netherlands), Doppler ultrasonic investigation of blood vessels («Aplia-XG-Toshiba», Japan) and biomicroscopy of vessels of the conjunctiva (slit lamp "Haag-Streit-Bern-900", Switzerland). Determined also instrumental vascular index $(\Psi)$, wherein each average indicator in patient $(\mathrm{X})$ with its standard deviation $(\varsigma)$ were evaluated in 1 point in case of $<\mathrm{X}+\varsigma$, when $\mathrm{X}+\varsigma \leftrightarrow \mathrm{X}+2 \varsigma-$ in 2 points, when $\mathrm{X}+2 \varsigma \leftrightarrow \mathrm{X}+3 \varsigma-$ in 3 points, at $>X+3 \varsigma$ - in 4 points. Calculated $\Psi$ per patient according to the formula: $\Psi=(\mathrm{A}+2 \mathrm{~B}+3 \Gamma+4 \Delta)$ : $\mathrm{E}$, where $« \mathrm{~A}, \mathrm{~B}, \Gamma$, $\Delta \gg-$ the number of patients accordingly to the $1,2,3$ and 4 points, «E»-the number of indicators.

Using biochemical analyzer "Olympus-AU-640" (Japan) were investigated the creatinine, immunoglobulin (Ig) A and rheumatoid factor (RF) concentrations in serum, examined levels of antibodies to native deoxyribonucleic acid (aDNA), cardiolipin (aCL), anti-cyclic citrullinated peptide antibody (aCCP), VEGF indicators, ET1, thromboxane-A2 (TxA2), homocysteine (hCys), prostacyclin (PgI2), cyclic guanosine monophosphate (cGMP), ESel, P selectin (PSel), using the immune-enzyme analysis (reader «PR2100 Sanofi diagnostic pasteur», France), and by immunoblotting method (apparatus «Euroline-Euroimmun», Germany) determined antinuclear factor (ANF) and anti-neutrophil cytoplasmic antibody (ANCA) - to myeloperoxidase (aMP) and proteinase-3 (aP3).

Seropositivity of SLE by ANF presence was met in $85.4 \%$ of patients, by aDNA - in $68.3 \%$ and aCL in $31.7 \%$; seropositivity of RA by RF ( $>14 \mathrm{IU} / \mathrm{mL})-$ in $53.0 \%$ and aCCP $(>17 \mathrm{U} / \mathrm{ml})$ - in $94.1 \%$; seropositivity of HSP by $\operatorname{IgA}(>3 \mathrm{mmol} / \mathrm{l})$ - in $41.7 \%$ and by RF - in $29.2 \%$; MPA seropositivity by ANCA was in all cases, and the ratio aMP to aP3 was as a 5: 1 . For the evaluation of renal function was used defining glomerular filtration rate (GFR) using CKD-EPI formula. To study the integral index of VED $(\Theta)$ was calculated the degree of vasoconstrictor indicators changes $(\Delta)$ - VEGF, ET1 and TxA2 and vasodilator PgI2 using formula: $\mathrm{X}=\left[\left(\mathrm{I}_{1}-\mathrm{I}_{2}\right): \mathrm{S}\right]^{2}$, where $I_{1}$ and $I_{2}$ - indicators at sick and healthy, $\varsigma$ - the standard deviation of the healthy. $\Theta$ determined by the formula:

$$
\Theta=\sqrt{(\mathrm{K}+\Lambda+\mathrm{M}): \mathrm{N}},
$$

where $\langle\mathrm{K} »-\mathrm{VEGF},\langle\Lambda »-\mathrm{ET} 1,\langle\mathrm{M} »-\mathrm{TxA} 2,\langle\mathrm{~N} »-$ PgI2 (VED diagnosed in $\Theta>5$ r.u). As a control, laboratory parameters were studied in 30 healthy subjects (13 men and 17 women aged 18-65 years).

Kidney biopsy was performed on the background of ataralgesia by controlling of kidney ultrasound. We used the technique of «True-Cut» («the present cutoff») with «Biopty-Bard» high-speed gun. Histological sections of the kidneys were stained with hematoxylin-eosin, alcian blue (on glycoproteins) and Van Gieson (collagen and elastic fibers), becoming the PAS-reaction. In addition, the enzyme immunoassay (with peroxidase labele) and immunofluorescence methods of kidney tissue research were performed. $\operatorname{IgA}, \operatorname{IgG}, \operatorname{IgM}$ deposits, C3- and Cq1- complement components were studied. Microscopic examination was performed on a microscope «Olympus-AX40» and «Olympus-AX70-Provis» with a digital video camera «Olympus-DP50». Renal failure of individual structures (glomeruli, tubules, stroma and vessels) were scored (from 0 to 3). Also there was calculated average damage indicator $(\theta)$ according to the formula: $\theta=(\alpha+2 \beta+3 \gamma):(\alpha+\beta+\gamma+\delta)$, where $\langle\alpha, \beta, \gamma »-$ the number of patients correspondingly with 1,2 and 3 points and $\langle\delta »-$ the number of patients with the absence of this sign.

Kidney biopsy is performed only in patients with the presence of proteinuria; nephrotic syndrome had 4 patients with SLE, 2 with RA and 2 with HSP. Ratio of CKD I, II, III and IV stages in SLE was as 10:7:2:1, in RA - 9:5:2:1, in HSP - 4:4:1:1, MPA - 5:4:2:1, and the average GFR in these groups was about the same, amounting to $96,1 \pm 4,17 \mathrm{ml} / \mathrm{min} / 1.73 \mathrm{~m}^{2}, 97,0 \pm 7,35 \mathrm{ml} / \mathrm{min} /$ $1.73 \mathrm{~m}^{2}, 100,7 \pm 3,61 \mathrm{ml} / \mathrm{min} / 1.73 \mathrm{~m}^{2}, 88,4 \pm 7,12 \mathrm{ml} / \mathrm{min} /$ $1.73 \mathrm{~m}^{2}$. In RA, patients with secondary AA-amyloidosis of the kidneys were excluded. In the survey group consisted of persons suffering from RGN the ratio of mesangioproliferative to mesangiocapillary RGN was as 2:1. Ratio of II:III:V:IV class of LGN frequency was as 1:2:4:13, and V:VI: IV:III:II type of Henoch-Schönlein purpura nephritis (HSPN) - 1:3:4:6:10. It should be emphasized that all 94 examined patients with SRD had tubulointerstitial changes in their kidneys.

Statistical analysis of the results of research was conducted by computer variation, correlation, regression, single-factor (ANOVA) and multivariate (ANOVA/ MANOVA) analysis of variance (program «Microsoft Excel» and «Statistica-Stat-Soft», USA). Assessed mean values $(\mathrm{X})$, their standard deviations $(\zeta)$ and error rates $(\mu)$, coefficient of parametric Pearson correlation (r) and nonparametric Kendall $(\tau)$, regression criteria $(R)$, dispersion Brown-Forsythe (BF) and Wilcoxon-Rao (WR), McNemar-Fisher criteria, Student's test (t) and the probability of statistical indicators (p).

\section{Results}

Noteworthy the fact definite quantified differences of kidneys vascular lesions nature in the individual SRD. So, $\theta$ in RA patients was $0,43 \pm 0,050$ r.u., in cases HSP $-0,69 \pm 0,059$ r.u., SLE - 0,89 $\pm 0,043$ r.u., MPA $1,01 \pm 0,130$ r.u. VED established in $35.3 \%, 51.9 \%, 39.0 \%$ and $100.0 \%$ of those surveyed, and $\Theta$ was $4,5 \pm 0,36$ r.u., $5,3 \pm 0,35$ r.u., $4,8 \pm 0,14$ r.u. and $6,5 \pm 0,55$ r.u.

The frequency of certain morphological characters of vascular endothelium at SRD is presented in Table. 1.

According to performed ANOVA/MANOVA, SRD nosological forms have a highly significant $(p<0,001)$ influence on the integral state of capillary endothelium $(\mathrm{WR}=3,60)$ and arterioles $(\mathrm{WR}=2,29)$. In multivariate Wilcoxon-Rao analysis, the lesion of the capillaries endothelium and arterioles of the kidneys depend on the cutaneous syndrome severity (consequently $\mathrm{WR}=2,49$, $\mathrm{p}=0,002$ and $\mathrm{WR}=2,05, \mathrm{p}=0,027)$, as well as peripheral neuropathy ( $\mathrm{WR}=1,92, \mathrm{p}=0,022$ and $\mathrm{WR}=1,97, \mathrm{p}=0,035$ ). 
Table 1 on background of unchanged concentration of

The frequency of the certain features of vascular endothelium lesion and the accuracy of the impact on them the integrated clinical and instrumental indicators of vascular disease in patients with SRD

\begin{tabular}{|c|c|c|c|c|c|c|c|}
\hline \multirow{3}{*}{$\begin{array}{c}\text { Morphological } \\
\text { signs of } \\
\text { vascular } \\
\text { endothelial } \\
\text { lesion } \\
\end{array}$} & & \multicolumn{4}{|c|}{$\begin{array}{c}\text { Groups of patients with } \\
\text { SRD }\end{array}$} & \multicolumn{2}{|c|}{$\begin{array}{l}\text { Integrated } \\
\text { indicators }\end{array}$} \\
\hline & SLE & RA & HSP & MPA & $\Omega$ & $\Psi$ & \\
\hline & \multicolumn{4}{|c|}{ frequency of symptoms, ( \%) } & \multicolumn{2}{|c|}{$\begin{array}{l}\text { degree of im- } \\
\text { pact, (p BF) }\end{array}$} & \\
\hline \multirow{2}{*}{$\begin{array}{l}\text { Endothelium } \\
\text { proliferation }\end{array}$} & capillaries & 97,6 & 17,7 & 33,3 & 91,7 & 0,461 & 0,555 \\
\hline & arterioles & 29,3 & 17,7 & 54,2 & 83,3 & 0,629 & 0,509 \\
\hline \multirow{5}{*}{$\begin{array}{l}\text { Deposits in } \\
\text { capillaries }\end{array}$} & IgA & 90,3 & 82,4 & 100,0 & 100,0 & 0,048 & 0,124 \\
\hline & $\operatorname{IgG}$ & 92,7 & 94,1 & 91,7 & 91,7 & 0,792 & 0,572 \\
\hline & IgM & 95,1 & 88,2 & 75,0 & 91,7 & 0,493 & 0,295 \\
\hline & $\mathrm{C} 3$ & 65,9 & 54,0 & 41,7 & 50,0 & 0,451 & 0,831 \\
\hline & $\mathrm{C} 1 \mathrm{q}$ & 48,8 & 11,9 & 25,0 & 58,3 & 0,724 & 0,529 \\
\hline \multirow{5}{*}{$\begin{array}{l}\text { Deposits in } \\
\text { arterioles }\end{array}$} & $\operatorname{Ig} \mathrm{A}$ & 22,0 & 23,5 & 54,2 & 33,3 & 0,019 & 0,364 \\
\hline & $\operatorname{IgG}$ & 29,3 & 23,5 & 37,5 & 33,3 & 0,036 & 0,709 \\
\hline & IgM & 29,3 & 5,9 & 16,7 & 25,0 & 0,635 & 0,536 \\
\hline & $\mathrm{C} 3$ & 22,0 & 5,9 & 12,5 & 25,0 & 0,614 & 0,509 \\
\hline & $\mathrm{C} 1 \mathrm{q}$ & 19,5 & 5,9 & 4,2 & 25,0 & 0,545 & 0,115 \\
\hline
\end{tabular}

The presence of VED has an impact on the nature of arteriolar endothelial changes ( $\mathrm{WR}=1,47, \mathrm{p}=0,046)$. In patients with SLE indicators of system VED effect on capillary endothelial damage $(\mathrm{WR}=2,95, \mathrm{p}=0,042)$, which is confirmed by the direct dependence of integrated morphological parameters of $\Theta(R=+7,42, p<0,001)$. In addition, multiple regression analysis set positive relationship $\Theta$ with changes of capillaries endothelium and arterioles at HSP (correspondingly $\mathrm{R}=+2,98, \mathrm{p}=0,008$ and $\mathrm{R}=+9,73, \mathrm{p}<0,001)$ and MPA $(\mathrm{R}=+6,81, \mathrm{p}=0,001$ and $\mathrm{R}=+6,50, \mathrm{p}=0,002)$.

Indicators of vascular endothelial function in healthy subjects in the control group and patients with SRD reflected in the Table 2. $(\mathrm{M} \pm \mathrm{m})$

\begin{tabular}{|c|c|c|c|c|c|}
\hline \multirow{2}{*}{ Indicators } & \multicolumn{5}{|c|}{ Groups of patients with SRD } \\
\cline { 2 - 6 } & $\begin{array}{c}\text { Healthy } \\
(\mathrm{n}=30)\end{array}$ & $\begin{array}{c}\text { SLE } \\
(\mathrm{n}=41)\end{array}$ & $\begin{array}{c}\text { RA } \\
(\mathrm{n}=17)\end{array}$ & $\begin{array}{c}\text { HSP } \\
(\mathrm{n}=24)\end{array}$ & $\begin{array}{c}\text { MPA } \\
(\mathrm{n}=12)\end{array}$ \\
\hline VEGF, pg/ml & $90,0 \pm 5,28$ & $534,3 \pm 11,63^{*}$ & $109,2 \pm 8,60$ & $515,5 \pm 12,98^{*}$ & $545,0 \pm 22,46^{*}$ \\
\hline ET1, pg/ml & $4,0 \pm 0,10$ & $7,8 \pm 0,36^{*}$ & $5,7 \pm 0,43^{*}$ & $7,9 \pm 0,48^{*}$ & $7,7 \pm 0,55^{*}$ \\
\hline TxA2, ng/ml & $8,0 \pm 1,56$ & $9,5 \pm 0,47$ & $9,6 \pm 0,79$ & $10,1 \pm 0,57$ & $10,9 \pm 1,28$ \\
\hline HCys, $\mathrm{mcmol} / 1$ & $9,3 \pm 0,48$ & $16,0 \pm 0,66^{*}$ & $16,2 \pm 0,86^{*}$ & $16,5 \pm 0,76^{*}$ & $16,9 \pm 1,17^{*}$ \\
\hline PgI2, ng/ml & $72,6 \pm 9,01$ & $18,4 \pm 1,06^{*}$ & $18,8 \pm 1,66^{*}$ & $17,7 \pm 1,19^{*}$ & $19,1 \pm 1,93^{*}$ \\
\hline $\mathrm{cGMP}, \mathrm{pmol} / \mathrm{ml}$ & $11,2 \pm 0,20$ & $13,6 \pm 0,48^{*}$ & $13,4 \pm 0,70^{*}$ & $12,8 \pm 0,55^{*}$ & $12,9 \pm 0,66^{*}$ \\
\hline ESel, ng/ml & $246,7 \pm 12,12$ & $230,1 \pm 6,30$ & $211,9 \pm 3,18^{*}$ & $227,7 \pm 6,27$ & $214,1 \pm 8,88$ \\
\hline PSel, ng/ml & $41,1 \pm 1,41$ & $48,9 \pm 1,54^{*}$ & $47,9 \pm 1,82^{*}$ & $47,6 \pm 1,79^{*}$ & $49,1 \pm 2,96^{*}$ \\
\hline
\end{tabular}

Note: $*$ - the differences between similar indeces of ill and healthy patients are statistically significant $(p<0,05)$

The similarity for all SRD was significantly higher parameters of ET1, HCys, cGMP and PSel in the blood elevated levels of VEGF and only in this group stated reduction of ESel.

In patients with LGN $\Theta$ index affects the proliferation of capillaries and glomerular endothelium $(\mathrm{BF}=3,38, \mathrm{p}=0,028)$, and arterioles $(\mathrm{BF}=3,25$, $\mathrm{p}=0,033)$, which demonstrates the Brown-Forsythe variance analysis. In turn, in RGN such connection concerns only arteriolar endothelium $(\mathrm{BF}=10,81$, $\mathrm{p}=0,002)$, while the MPA - capillaries $(\mathrm{BF}=5,29$, $\mathrm{p}=0,027)$.

\section{Discussion}

The least significant vascular changes observed in RA, and the most pronounced - in MPA. The same results was got by Koseki at all during a 42-month observation period in prospective study of renal disease in patients with early rheumatoid arthritis: only in $7 \%$ of the patient with RA was developed persistent proteinuria and $6 \%$ presented elevated serum creatinine with or without proteinuria. [27]. These abnormalities were mostly drug-related and reversible after discontinuation of the treatment $[8,10]$. On renal biopsy, MPA typically presents as a pauci-immune (devoid of immune complexes), necrotizing and crescentic glomerulonephritis - which is why renal MPA often presents as a rapid progressive disease with advanced stage of renal failure [12]. Only the group of patients with SLE and MPA did not differ in frequency of immune deposits in the kidneys blood vessels that demonstrate fulfilled McNemar-Fischer analysis. Lupus and necrotizing nephritis determines long-term morbidity and mortality in SLE and MPA because renal failure in SRD is associated with a large number of secondary and tertiary complications $[12,16]$.

The proliferation of capillary endothelium to a greater extent has been characteristic of SLE and MPA, and arteriolar endothelium - only of the MPA, whereas

Table 2 these changes were not characteristic for RA. Despite some differences in the clinic of primary systemic necrotizing vasculitis MPA and systemic autoimmune diseases - SLE, they share a number of common pathogenetic mechanisms, which are based on immunological process $[15,16]$.

As expected, IgA deposits in the blood vessels were the most typical to Henoch-Schönlein purpura nephritis, because its a small vessel vasculitis mediated by IgA-immune complex deposition [11], and Clq - for LGN and MPA, Clq deposits are usually found in association with other complement components and immunoglobulins in proliferative glomerulonephritis and may predominate in SLE 
and MPA [7]. C1q deposits were quasi-constantly found in SLE patients with or without skin lesions (90\%).

The clinical vascular manifestations of SRD are considered with the presence of skin purpura, telangiectasia, capillaritis of hands and feet, antiphospholipid syndrome, Raynaud's syndrome, uveitis, cheilitis, leukocytoclastic enantemy, peripheral vasoneuropathy, vascular encephalopathy and pulmonary hypertension.

With $\Psi$ index at SRD weakly related morphological characteristics of renal endothelium lesion. The vascular lesion confirm extensive previous data that immune complexes in vessels do not bind significantly to unstimulated endothelial cells [17].

In turn $\Omega$ has a significant impact on $\operatorname{Ig} \mathrm{A}$ deposition in the glomerular capillaries $(\mathrm{BF}=2,78, \mathrm{p}=0,048)$ and arterioles $(\mathrm{BF}=3,49, \mathrm{p}=0,019)$ as well as deposits $\mathrm{IgG}$ in arterioles $(\mathrm{BF}=2,99, \mathrm{p}=0,036)$ that showed with Brown-Forsythe variance analysis. According to the analysis Kendall, there are direct correlations $\Omega$ indices with $\operatorname{Ig}$ A deposition rate in capillaries $(\tau=+0,187$, $\mathrm{p}=0,005)$, and in renal arterioles $(\tau=+0,141, \mathrm{p}=0,036)$. With that said, the rate of $\Omega>1,5$ r.u. $(>X+\varsigma$ patients SRS) is a risk factor for high level of $\operatorname{IgA}$ deposits in the renal vascular endothelium. The pathogenesis of immune complex mechanism is characterized by the deposition in the different structure of the kidney tissue of immune deposits and Ig. As part of the deposited immune complexes is most often defined "full house" - the entire set of Ig and complement components. Immune complexes can be deposited not only in the glomeruli, but also in the tubular basement membrane and into the vessel walls. Different types of angiopathy can be observed in the glomerular aparatus at SRD [19].

In LGN $\Theta$ index closely related with deposition in glomerular capillary endothelium of $\mathrm{C} 3(\mathrm{BF}=3,96$, $\mathrm{p}=0,015)$, in HSGN- IgM $(\mathrm{BF}=3,19, \mathrm{p}=0,048)$, and with $\mathrm{MPA}-\operatorname{IgA}(\mathrm{BF}=7$ 99, $\mathrm{p}=0,010), \operatorname{IgG}(\mathrm{BF}=4,42, \mathrm{p}=0,041)$, $\operatorname{IgM}(B F=4,26, p=0,045), C 1 q(B F=20,24, p<0,001)$. The co-localization of $\mathrm{Ig}$ isotypes $\mathrm{IgG}, \mathrm{IgA}$ and $\operatorname{IgM}$ with C1q, C4 and C3 (the so called 'full house' pattern) in the glomeruli is almost exclusively present in glomeruli of patients with lupus nephritis [20]. Given that C3 is the common point connecting all three pathways in complement activation and is tightly regulated naturally, many of the studies in lupus mice have concentrated on activators and regulators of C3 [14].

Deposits in the kidneys arterioles in SLE concern $\mathrm{Clq}(\mathrm{BF}=23,63, \mathrm{p}<0,001)$, in $\mathrm{HSP}-\operatorname{IgA}(\mathrm{BF}=6,84$, $\mathrm{p}=0,002), \operatorname{IgG}(\mathrm{BF}=9,76, \mathrm{p}<0,001)$ and $\mathrm{Clq}(\mathrm{BF}=24,48$, $\mathrm{p}<0,001)$, in $\mathrm{RA}-\operatorname{IgA}(\mathrm{BF}=4,47, \mathrm{p}=0,032), \operatorname{IgG}(\mathrm{BF}=3,39$, $\mathrm{p}=0,048), \operatorname{IgM}(\mathrm{BF}=19,74, \mathrm{p}=0,001), \mathrm{C} 3 \quad(\mathrm{BF}=9,65, \mathrm{p}=$ $=0,007)$ and $\mathrm{Clq}(\mathrm{BF}=9,65, \mathrm{p}=0,007)$.

Renal vascular endothelium synthesizes vasoactive hormones such as endothelin, NO, prostacyclin, thromboxane, participating in vascular endothelial function, as well as factors of coagulation and inflammation that cause endothelial participation in the processes of regulation of renal function, inflammation, possible further sclerosis and destruction of nephrons [2]. Thus, VED is involved in the processes of deposition of immunoglobulins and complement components in the endothelium of the kidney vessels at all SRD, but RA characterized by deposits exclusively in the arterioles, and MPA - in glomerular capillaries, that is likely due to the nature of renal tissue destruction.

It is also noteworthy that in SLE patients, anti-Clq antibodies are associated with proliferative lupus nephritis, and anti-Clq antibody levels may indicate renal disease activity decreased $\mathrm{C} 3$ and $\mathrm{C} 4$ levels have been found in about $75 \%$ of SLE patients with focal nephritis and $90 \%$ in patients with diffuse nephritis [26]. Additionally, the co-localization of Ig isotypes IgG, IgA, and IgM with C1q, C4 and C3 (and C5b-9) (the so called "full house" pattern) in the glomeruli is almost exclusively present in glomeruli of patients with lupus nephritis and necrotising vasculitis in MPA [11]. Finally, complement split products such as C3d and C5b-9 can also be detected in the urine of SLE patients[16]. Impaired immune complexes handling plays an important role in the pathogenesis in LGN. Since the complement system is required at all steps of normal immune complexes metabolism, any number of alterations can lead to pathological glomerular immune complexes accumulation, particularly in conditions of immune complexes excess, as in SLE and MPA [26].

In addition to the dispersion relation, deposition $\mathrm{C} 3$ in the endothelium of the capillaries in SLE patients and $\mathrm{Clq}$ - in patients with MPA directly correlates with $\Theta$ parameter that reflects Kendall analysis (respectively $\tau=+0,224, p=0.045$ and $\tau=+0,464, p=0.036$ ). It can be considered in this regard that $\Theta>4$ r.u. in cases of LGN and $\Theta>8$ r.u. in cases of MPA ( $>\mathrm{X}+\varsigma$ appropriate patients) are prognosis negative criteria of deposition of complement components in the glomerular capillaries.

We have selected those indicators of endothelial function of blood vessels, with which some morphological characteristics of vascular endothelial kidney changes at the same time had both dispersion, and correlation relations. Thus, in LGN the degree of proliferation of glomerular capillaries endothelium directly depends on the content of ET1 $(B F=3,06, p=0,040$; $\tau=+0,234, p=0,031)$, and arteriolar endothelium - from ESel $(B F=3,06, p=0,040 ; \tau=+0,234, p=0,0311)$. IgG deposition in capillaries and arterioles in patients with RGN closely linked to the concentration of PSel (respectively $\mathrm{BF}=9,84, \mathrm{p}=0,002 ; \tau=+0,389, \mathrm{p}=0,029$ and $\mathrm{BF}=16,66$, $\mathrm{p}<0,001 ; \tau=+0,369, \mathrm{p}=0,039)$, and IgA in HSPN - with level of HCys $(B F=7,78, p=0,003 ; \tau=+0,449, p=0,002$ and $\mathrm{BF}=4,05, \mathrm{p}=0,033 ; \tau=+0,390, \mathrm{p}=0.030$ ). Patients with MPA on proliferation of glomerular endothelial affect the values of VEGF $(\mathrm{BF}=27,64, \mathrm{p}<0,001 ; \Theta=+0,436$, $p=0,049)$. We can assume that these factors of VED are involved in the pathogenesis of renal vascular damage constructions in different SRD. VED is considered as the consequence of a combination of elements including genetic predisposition, traditional cardiovascular risk factors and systemic inflammation. Therefore it is striking that in RA the contribution of systemic mediators of inflammation to VED is not yet elucidated [22]. VED is also associated with vascular complications in several 
systemic autoimmune diseases. Several published studies have demonstrated that VED from the sera of patients with MPA, HSP, SLE and RA was able to modulate endothelial cell function and activate endothelial cells, leading to the production of pro-inflammatory cytokines together with a pro-adhesive phenotype [28]. Likewise whether such circulating indices of systemic inflammation could be used as biomarkers of VED.

\section{Conclusions}

1. VED like an imbalance of vasoconstrictors VEGF, ET1, TxA2 and vasodilator PgI2 occurs in $35 \%$ of RA patients with renal lesion, in $39 \%$ of SLE, $52 \%$ with VSHG and $100 \%$ with MPA, participating in the pathogenesis of endothelial changes in glomerular arterioles and capillaries.

2. The morphological lesion of the endothelium of renal vessels are closely linked with the severity of clinical and instrumental signs of extrarenal systemic angiopathy (with skin lesions, mucous membranes and the peripheral nervous system, with parameters biomicroscopy of vessels of the conjunctiva and vasodilation of the brachial artery).

3. The proliferation of glomerular endothelium of patients with MPA determines serum concentration of VEGF, and in the development of renal endothelial immune deposits (IgA, IgG, IgM, C3, C1q) in LGN involved ET1 and ESel, in RGN - PSel, when HSPN - HCys.

\section{References}

1. Heijnen, T. Outcome of patients with systemic diseases admitted to the medical intensive care unit of a tertiary referral hospital: a single-centre retrospective study [Text] / T. Heijnen, A. Wilmer, D. Blockmans, L. Henckaerts // Scandinavian Journal of Rheumatology. - 2016. - Vol. 45, Issue 2. - P. 146-150. doi: 10.3109/03009742.2015.1067329

2. Kuo, C. F. Familial aggregation of systemic lupus erythematosus and coaggregation of autoimmune diseases in affected families [Text] / C. F. Kuo, M. J. Grainge, A. M. Valdes, L.-C. See, S.-F. Luo, K.-H. Yu et. al. // JAMA Internal Medicine. - 2015. Vol. 175, Issue 9. - P. 1518-1526. doi: 10.1001/jamainternmed.2015.3528

3. Ramos-Casals, M. Google-driven search for big data in autoimmune geoepidemiology: analysis of 394,827 patients with systemic autoimmune diseases [Text] / M. Ramos-Casals, P. Brito-Zerón, B. Kostov, A. Sisó-Almirall, X. Bosch, D. Buss et. al. // Autoimmunity Reviews. - 2015. - Vol. 14, Issue 8. - P. 670-679. doi: 10.1016/j.autrev.2015.03.008

4. Yang, Z. Prevalence of systemic autoimmune rheumatic diseases and clinical significance of ANA profile: data from a tertiary hospital in Shanghai, China [Text] / Z. Yang, Y. Ren, D. Liu, F. Lin, Y. Liang // APMIS. - 2016. - Vol. 124, Issue 9. - P. 805-811. doi: 10.1111/apm.12564

5. De Groot, K. Nierenmanifestationen bei rheumatischen Erkrankungen [Text] / K. De Groot // Der Internist. - 2007. - Vol. 48, Issue 8. - P. 779-785. doi: 10.1007/s00108-007-1887-9

6. Dey-Rao, R. Genome-wide transcriptional profiling data from chronic cutaneous lupus erythematosus (CCLE) peripheral blood [Text] / R. Dey-Rao, A. A. Sinha // Data Brief. - 2014. - Vol. 2. - P. 39-41. doi: 10.1016/j.dib.2014.11.006

7. Maldonado, A. Medium vessel vasculitis in systemic lupus erythematosus [Text] / A. Maldonado, J. N. Blanzari, P. Asbert, J. A. Albiero, C. Gobbi, E. Albiero, P. Alba // Rev. Fac. Cien. Med. Univ. Nac. Cordoba. - 2016. - Vol. 73, Issue 1. - P. $50-52$.

8. Baerwald, C. Extraartikuläre Manifestationen der rheumatoiden Arthritis [Text] / C. Baerwald, C. Kneitz, M. Bach, M. Licht // Zeitschrift für Rheumatologie. - 2012. - Vol. 71, Issue 10. - P. 841-849. doi: 10.1007/s00393-011-0928-x

9. Elshabrawy, H. A. The pathogenic role of angiogenesis in rheumatoid arthritis [Text] / H. A. Elshabrawy, Z. Chen, M. V. Volin, S. Ravella, S. Virupannavar, S. Shahrara // Angiogenesis. - 2015. - Vol. 18, Issue 4. - P. 433-448. doi: 10.1007/ s10456-015-9477-2

10. Haavisto, M. Influence of triple disease modifying anti-rheumatic drug therapy on carotid artery inflammation in drug-naive patients with recent onset of rheumatoid arthritis [Text] / M. Haavisto, A. Saraste, L. Pirilä, J. C. Hannukainen, K. K. Kalliokoski, A. Kirjavainen et. al. // Rheumatology. - 2016. - Vol. 55, Issue 10. - P. 1777-1785. doi: 10.1093/rheumatology/kew240

11. Hoffman, G. S. Vasculitis: determinants of disease patterns [Text] / G. S. Hoffman, L. H. Calabrese // Nature Reviews Rheumatology. - 2014. - Vol. 10, Issue 8. - P. 454-462. doi: 10.1038/nrrheum.2014.89

12. Holle, J. U. ANCA-assoziierte Vaskulitiden [Text] / J. U. Holle // Der Internist. - 2014. - Vol. 56, Issue 1. - P. 41-52. doi: 10.1007/s00108-014-3613-8

13. Petrucci, I. Clinical Scenarios in Chronic Kidney Disease: Parenchymal Chronic Renal Diseases - Part 2 [Text] / I. Petrucci, S. Samoni, M. Meola // Contributions to Nephrology. - 2016. - Vol. 188. - P. 98-107. doi: 10.1159/000445472

14. Wilhelmus, S. The Revisited classification of GN in SLE at 10 years: Time to re-eEvaluate histopathologic lesions [Text] / S. Wilhelmus, C. E. Alpers, H. T. Cook, F. Ferrario, A. B. Fogo, M. Haas et. al. // Journal of the American Society of Nephrology. 2015. - Vol. 26, Issue 12. - P. 2938-2946. doi: 10.1681/asn.2015040384

15. Rawlings, C. R. A rheumatology perspective on cutaneous vasculitis: assessment and investigation for the non-rheumatologist [Text] / C. R. Rawlings, G. A. Fremlin, J. Nash, K. Harding // International Wound Journal. - 2015. - Vol. 13, Issue 1. - P. 17-21. doi: 10.1111/iwj.12437

16. Song, D. The spectrum of renal thrombotic microangiopathy in lupus nephritis [Text] / D. Song, L. H. Wu, F. Wang, X. Yang, D. Zhu, M. Chen et. al. // Arthritis Research \& Therapy. - 2013. - Vol. 15, Issue 1. - P. R12. doi: 10.1186/ar4142

17. Marszałek, A. Patient with rheumatoid arthritis and acute renal failure: a case report and review of literature [Text] / A. Marszałek, N. Skoczylas-Makowska, A. Kardymowicz, J. Manitius // Polish Journal of Pathology. - 2010. - Vol. 61, Issue 4. P. 229-233. 
18. Tesar, V. Conventional induction and maintenance treatment of antineutrophil cytoplasmic antibodies-associated vasculitis - still of value for our patients? [Text] / V. Tesar, Z. Hruskova // Expert Opinion on Pharmacotherapy. - 2015. - Vol. 16, Issue 11. P. 1683-1702. doi: 10.1517/14656566.2015.1059822

19. Ferrante, A. Endothelial progenitor cells: Are they displaying a function in autoimmune disorders? [Text] / A. Ferrante, G. Guggino, D. Di Liberto, F. Ciccia, P. Cipriani, C. R. Balistreri et. al. // Mechanisms of Ageing and Development. - 2016. - Vol. 3, Issue 5. - P. 122-128. doi: 10.1016/j.mad.2016.05.001

20. Yildiz, A. Diastolic dysfunction and endothelial dysfunction in systemic lupus erythematosus [Text] / A. Yildiz, S. Soydinc // Rheumatology International. - 2015. - Vol. 35, Issue 7. - P. 1281-1282. doi: 10.1007/s00296-015-3220-6

21. Ding, Y. Association of miRNA-145 expression in vascular smooth muscle cells with vascular damages in patients with lupus nephritis [Text] / Y. Ding, W. Liao, Z. Yi, W. Xiang, X. He // International Journal of Clinical and Experimental Pathology. 2015. - Vol. 8, Issue 10. - P. 12646-12656.

22. Latuskiewicz-Potemska, J. Nailfold capillaroscopy assessment of microcirculation abnormalities and endothelial dysfunction in children with primary or secondary Raynaud syndrome [Text] / J. Latuskiewicz-Potemska, A. Chmura-Skirlinska, R. J. Gurbiel, E. Smolewska // Clinical Rheumatology. - 2016. - Vol. 35, Issue 8. - P. 1993-2001. doi: 10.1007/s10067-016-3340-8

23. Fujita, E. Glomerular capillary and endothelial cell injury is associated with the formation of necrotizing and crescentic lesions in crescentic glomerulonephritis [Text] / E. Fujita, K. Nagahama, A. Shimizu, M. Aoki, S. Higo, F. Yasuda et. al. // Journal of Nippon Medical School. - 2015. - Vol. 82, Issue 1. - P. 27-35. doi: 10.1272/jnms.82.27

24. Palma Zochio Tozzato, G. Collagen-induced arthritis increases inducible nitric oxide synthase not only in aorta but also in the cardiac and renal microcirculation of mice [Text] / G. Palma Zochio Tozzato, E. F. Taipeiro, M. A. Spadella, P. Marabini Filho, M. R. de Assis, C. P. Carlos et. al. // Clinical \& Experimental Immunology. - 2016. - Vol. 183, Issue 3. - P. 341-349. doi: 10.1111/ cei. 12728

25. Gonzalez-Suarez, I. Brain microvasculature involvement in ANCA positive vasculitis [Text] / I. Gonzalez-Suarez, J. Arpa, J. J. Rios-Blanco // Cerebrovascular Diseases. - 2016. - Vol. 41, Issue 5-6. - P. 313-321. doi: 10.1159/000443750

26. Guo, L. Anti-endothelin receptor type a autoantibodies in systemic lupus erythematosus-associated pulmonary arterial hypertension [Text] / L. Guo, M. Li, Y. Chen, Q. Wang, Z. Tian, S. Pan et. al. // Arthritis \& Rheumatology. - 2015. - Vol. 67, Issue 9. - P. 2394-2402. doi: 10.1002/art.39212

27. Koseki, Y. A prospective study of renal disease in patients with early rheumatoid arthritis [Text] / Y. Koseki // Annals of the Rheumatic Diseases. - 2001. - Vol. 60, Issue 4. - P. 327-331. doi: 10.1136/ard.60.4.327

28. Constans, J. Anti-endothelial cell autoantibodies and soluble markers of endothelial cell dysfunction in systemic lupus erythematosus [Text] / J. Constans, R. Dupuy, A. D. Blann et. al. // The Journal of Rheumatology. - 2003. - Vol. 30, Issue 9. P. $1963-1966$.

Рекомендовано до публікаиії д-р мед. наук Ханюков О. О. Дата надходження рукопису 16.01.2017

Iegudina Yelizaveta, $\mathrm{PhD}$, Associate professor, Department of the propedeutic of the internal medicine, SE "Dnipropetrovsk Medical Academy” of Health Ministry of Ukraine, V. Vernads'kogo str., 9, Dnipro, Ukraine, 49044 E-mail: elizavetaegudina@gmail.com 